\title{
Pemodelan Homologi Komparatif Struktur 3D Protein Dalam Desain dan Pengembangan Obat
}

\author{
Fredy Z Saudale* \\ Program Studi kimia, Fakultas Sains dan Teknik, Universitas Nusa Cendana, Kupang \\ Nusa Tenggara Timur, Indonesia \\ *Corresponding Author: fredysaudale@staf.undana.ac.id \\ Received: February,20,2020 /Accepted: June,29,2020 \\ doi: $10.24252 /$ al-kimiav8i1.9463
}

\begin{abstract}
One of the strategies applied in the initial steps of drug design and discovery is by utilizing the availability of $3 D$ protein structures. However, most of the functional protein structures have not been fully obtained experimentally to date. This is due to the difficulty of procedures, the high cost, and the length of time required from structural biology experiments such as $X$-ray crystallography. Comparative homology modeling is a computational method that is proven to be accurate in predicting the structure of $3 D$ target proteins with a ratio of $30 \%$ similarity to the arrangement of amino acids in the structure of the template proteins. This review attempts to explain comparative homology modeling methods such as MODELLER, PHYRE2, SWISS-MODEL, its iterative steps in predicting and building $3 D$ protein target models, its evaluation and validation of protein models as well as the examples of their application in drug design and development targeting GPCR proteins, Zika virus RNA polymerase, and HIV protease. With this, comparative homology modeling can be very useful to accelerate research on drug design and development in dealing with diseases and health problems that still exist in the society.
\end{abstract}

Key word: computational, homology, modeling, protein, 3D-structure

\section{PENDAHULUAN}

Protein adalah biopolimer yang tersusun atas asam amino linear yang urutannya menentukan struktur tiga dimensi (3D). Struktur 3D asli ini (native) memungkinkan protein untuk menjalankan banyak fungsi biokimia penting dalam kehidupan (Orengo et al., 1999). Implikasinya adalah bahwa pemahaman terperinci tentang biokimia protein membutuhkan tidak hanya pengetahuan tentang urutan asam amino penyusunnya, tetapi juga pengetahuan tentang bagaimana urutan tersebut terlipat secara spasial (folding) membentuk struktur 3D protein (Moult \& Melamud, 2000). Penentuan struktur 3D protein dapat memberikan detail penting tentang fungsi dan mekanisme kerja biologis. Karakterisasi paling akurat dari struktur 3D protein disediakan melalui eksperimen biologi struktural seperti kristalografi sinar-X (Shi, 2014). Namun, ketersediaan struktur 3D yang akurat dari sebagian besar protein belum sepenuhnya berhasil didapatkan secara eksperimental hingga saat ini (Davis et al., 2003). Hal ini disebabkan karena sulitnya prosedur, mahalnya biaya dan lamanya waktu yang dibutuhkan dari eksperimen biologi struktural (Slabinski et al., 2007). Akibatnya jumlah struktur protein yang tersedia tidak sebanding atau masih jauh lebih kecil dibandingkan jumlah sekuen protein yang berhasil diurutkan (Schwede, 2013). Bersyukur dengan kemajuan teknologi pemetaan genom juga DNA yang mengkode protein dan ilmu bioinformatika, salah satu pendekatan yang menjanjikan untuk menutup kesenjangan ini adalah dengan menerapkan metode komputasional dalam pemodelan molekuler (Skolnick \& Fetrow, 2000). Pengembangan metode komputasi untuk memprediksi struktur 3D protein secara akurat dari sekuen asam amino penyusunnya telah banyak diterapkan secara khusus pada tahapan awal desain dan pengembangan obat (Hillisch \& Hilgenfeld, 2003; Nero et al., 2018; Saudale, 2020; Saudale et al., 2019). 

dan pengembangan obat

\section{METODE PENELITIAN \\ Modeller}

Modeller mengimplemetasikan pemodelan homologi komparatif berdasarkan pemenuhan parameter spasial, statistik dan stereokimia (Eswar et al., 2006). Modeller memprediksi model protein secara spasial berdasarkan data sudut-sudut dihedral dan jarak yang didapat dari analisis penjajaran target dengan template yang dioptimalisasikan melalui simulasi dinamika molekuler. Secara stereokimia, Modeller mendapatkan preferensi sudut-sudut ikatan dan panjang ikatan dari medan gaya (force-field) mekanika molekuler CHARMM-22. Secara statistik, Modeller mendapatkan preferensi sudut-sudut dihedral, jarak antar atom yang tidak berikatan dari sekumpulan representatif strukturstruktur protein yang telah diketahui secara eksperimental di PDB. Semua parameter spasial, stereokimia dan statistik ini kemudian diintegrasikan menjadi suatu fungsi obyektif yang kemudian dioptimalisasikan untuk mendapatkan model 3D final protein target protein (Webb \& Sali, 2017). Input dari program Modeller adalah file penjajaran asam-asam amino protein target dengan template dan script sederhana menggunakan bahasa pemrograman Python 3.6. Modeller kemudian secara otomatis melakukan kalkulasi dan membangun model protein yang terdiri atas semua atom-atom non-hidrogen.

\section{Phyre2}

Kekuatan dari metode Phyre2 adalah bahwa prediksi struktur 3D protein target tidak hanya didasarkan atas protein homolog yang dekat secara evolusi (close), tapi juga yang jauh (remote) (Kelley et al., 2015). Protein homolog yang dekat secara evolusi mempunyai struktur dan susunan asam amino dengan kemiripan tinggi. Sementara protein homolog yang jauh secara evolusi mempunyai kemiripan struktur namun tidak dalam susunan asam aminonya. Kemiripan susunan asam amino dibawah $20 \%$ umumnya menjadi parameter yang menentukan protein homolog yang jauh secara evolusi. Phyre2 pertama-tama membangun profil evolusi dari protein target dengan cara mengumpulkan sejumlah besar protein homolog yang beragam baik yang jauh maupun dekat secara evolusi. Ini dilakukan dengan metode HHblits (Remmert et al., 2012). HHblits digunakan untuk memindai sekuen asam amino protein target (query sequence) terhadap sekuen asam amino protein-protein di database yang tidak memiliki identitas di atas $20 \%$. Proses ini menghasilkan suatu profil sekuen yang ditampilkan dalam bentuk penjajaran sekuen jamak (multiple sequence alignment) yang juga digunakan untuk memprediksi keberadaan struktur sekunder (secondary structure prediction) seperti $\alpha$-heliks, lembaran- $\beta$ dan coil menggunakan metode PSIPRED (Jones, 1999). Fragmen-fragmen lipatan kemudian diidentifikas di dalam database (fold library scanning) dari struktur protein-protein yang telah diketahui dalam bentuk penjajaran sekuen. Hasil penjajaran ini digunakan untuk menghasilkan model rantai utama protein yang masih kasar (crude backbone) yang belum memiliki rantai samping dan terkadang juga terdapat insersi (penyisipan asam amino baru) dan delesi (penghapusan asam amino yang ada). Loop dan rantai samping kemudian ditambahkan untuk menghasilkan struktur model yang lengkap.

\section{Swiss-Model}

Swiss-Model adalah server otomatis untuk pemodelan komparatif struktur 3D protein (Schwede et al., 2003). Swiss-Model memelopori bidang pemodelan otomatis mulai tahun 1993 dan merupakan fasilitas pemodelan otomatis berbasis web gratis yang paling banyak digunakan saat ini. Swiss-Model mengintegrasikan program dan database yang diperlukan untuk pemodelan struktur protein di ruang kerja berbasis web. Input data 
adalah urutan asam amino dari protein target yang dikirimkan untuk membangun model 3D. Pemilihan template, analisis penjajaran dan pembuatan model dilakukan sepenuhnya secara otomatis oleh server.

\section{HASIL DAN PEMBAHASAN}

\section{Evaluasi, Validasi Dan Penyempurnaan Model}

\section{SAVES v5.0}

SAVES (Structure Analysis and Verification Server) v5.0 (http://servicesn.mbi.ucla.edu/SAVES/) mengintegrasikan 5 program validasi struktural yaitu VERIFY 3D, ERRAT, PROVE, PROCHECK dan WHATCHECK. VERIFY 3D memeriksa kompatibilitas struktur model 3D protein berdasarkan letak residu penyusun dan membandingkannya dengan struktur eksperimental yang tersedia (Eisenberg et al., 1997). ERRAT memverifikasi keakuratan interaksi-interaksi non-ikatan antara berbagai jenis atom di dalam struktur model berdasarkan perbandingan parameter statistik menggunakan struktur eksperimental dengan resolusi tinggi (Colovos \& Yeates, 1993). PROVE menghitung penyimpangan statistik (z-score) model dari struktur eksperimental dengan membandingkan volume atom-atomnya (Pontius et al., 1996). PROCHECK menilai kualitas stereokimia protein berdasarkan analisis geometri residu-residu asam amino penyusun model struktur yang dibandingkan dengan struktur protein eksperimental resolusi tinggi dan menampilkannya dalam bentuk diagram Ramachandran (Laskowski et al., 1993). WHATCHECK melakukan perhitungan secara lebih ekstensif terhadap parameter-parameter stereo-kimia (HOOFT, 1996).

\section{ProSA}

ProSA (Protein Structure Analysis) merupakan server yang digunakan untuk memeriksa kesalahan-kesalahan potensial dari model 3D protein. ProSA (https://prosa.services.came.sbg.ac.at/prosa.php) membutuhkan koordinat atom-atom $(\mathrm{x}, \mathrm{y}, \mathrm{z})$ dari model yang akan dievaluasi yang terdapat dalam bentuk file PDB. ProSA hanya membutuhkan informasi atom $\mathrm{C} \alpha$ dari model dalam analisisnya. Aplikasi ProSA menampilkan skor dan plot energi dari struktur protein yang dianalisis. Skor kualitas struktur protein ditampilkan dalam bentuk plot yang menunjukan deviasi skor model protein (z-score) dalam rentang skor dari semua protein yang telah ditentukan secara eksperimen dan tersimpan di PDB dan juga plot energi dari setiap residu asam amino penyusun. Nilai z-score dalam ProSA menunjukan kualitas model dan pengukuran penyimpangan energi yang berhubungan dengan distribusi energi model dibandingkan dengan struktur protein dalam PDB baik yang berasal dari kristalografi sinar-X atau NMR yang dibedakan berdasarkan warna pada grafik yang ditampilkan (Wiederstein \& Sippl, 2007). Nilai positif yang ditunjukan oleh plot energi residu dari ProSA menunjukan adanya kesalahan pada model protein. Secara umum energi residu dari model yang baik akan bernilai negatif dengan beberapa pengecualian pada daerah ujung (terminal $\mathrm{N}$ ) yang cenderung lebih fleksibel.

\section{Molprobity}

MolProbity (http://molprobity.biochem.duke.edu/) adalah layanan web validasi struktur yang menyediakan evaluasi kualitas model protein. MolProbity sangat bergantung pada kekuatan dan sensitivitas yang disediakan oleh penempatan atom hidrogen yang dioptimalkan dan juga analisis kontak antara semua-atom yang terjadi. Penambahan atom $\mathrm{H}$ dalam MolProbity berguna untuk menganalisis kontak semua atom. MolProbity 
menampilkan analisis kontak antara semua atom, ramachandran plot, dan distribusi rotamer (rantai samping). Kristalografi sinar-X yang digunakan sebagai cetakan (template) dalam pemodelan homologi komparatif, memberikan banyak data molekuler yang penting secara biologis dalam bentuk struktur atom 3D protein. Namun, demikian, kesalahan lokal dari pemodelan dapat mempengaruhi interpretasi biologis seperti residu asam amino yang ada di area yang dilarang dalam plot Ramachandran (outlier). MolProbity melakukan validasi dan evaluasi kualitas model struktur 3D protein yang ditampilkan dalam bentuk ringkasan, grafik, dan file yang dapat diunduh (Chen et al., 2010). Ketika antara atom-atom menunjukan adanya kontak dengan tumbukan yang serius maka ini akan dihitung sebagai nilai clash score. Clash score adalah jumlah tumbukan per 1000 atom yang akan dimuat dengan kode warna merah (buruk), kuning (sedang), atau hijau (bisa diterima) (Chen et al., 2010).

\section{Galaxy Refine}

Kualitas struktur model yang dihasilkan melalui pemodelan homologi komparatif sangat tergantung pada tingkat kesamaan antara target dan struktur template yang tersedia. Oleh karena itu, adalah juga penting untuk menyempurnakan kualitas model di luar informasi tentang keakuratan template yang dipakai. Server web Galaxy Refine (http://galaxy.seoklab.org/cgi-bin/submit.cgi?type=REFINE) didasarkan pada metode penyempurnaan dengan melakukan pemodelan ulang rantai samping residu asam amino. Galaxy Refine juga melakukan pengemasan rantai samping dan juga relaksasi keseluruhan struktur dengan simulasi dinamika molekul singkat selama 0,2 ps secara berulang (iterative) yang mampu merelaksasi, mengurangi ketegangan struktur dan meminimalkan energinya. Galaxy Refine menunjukkan kinerja terbaik dalam meningkatkan kualitas struktur lokal. Metode ini dapat meningkatkan kualitas struktur global dan lokal ketika digunakan untuk menyempurnakan struktur 3D protein yang dihasilkan melalui pemodelan molekuler. Data input yang dibutuhkan oleh Galaxy Refine adalah file PDB dari model protein. Proses penyempurnaan umumnya dilakukan 2-5 jam. Hasil atau output muncul dalam bentuk tabel yang berisi 5 model protein baru yang telah disempurnakan beserta data-data struktural seperti RMSD, nilai MolProbity, Clash score, Ramachandran plot, dan rantai samping (rotamers). Data di simpan di dalam server selama 30 hari. Model yang direkomendasikan oleh Galay Refine selanjutnya dapat dievaluasi dan divalidasi perbaikannya kembali secara iteratif dengan SAVES v5.0, ProSA dan MolProbity sebelum digunakan pada proses selanjutnya seperti dinamika molekuler, docking atau skrining virtual.

\section{Aplikasi}

Berikut ini diberikan beberapa contoh penerapan pemodelan homologi komparatif dalam desain dan pengembangan obat sindrom metabolik seperti obesitas, diabetes dan juga agen antiviral terhadap virus HIV dan ZIka (Tabel 5).

\section{Protein GPCRs}

Protein GPCRs ( $G$ Protein-Coupled Receptors) adalah protein reseptor transmembran yang mentransduksi sinyal ekstraseluler menjadi suatu respon biologis melalui aktivasi protein $\mathrm{G}$ heterotrimerik dan $\beta$-arestin (Hauser et al., 2017). GPCR terlibat dalam hampir setiap sistem biologis yang dikenal. Desain dan pengembangan molekul dengan berat molekul kecil yang berpotensi sebagai obat dengan menargetkan protein GPCR merupakan salah satu penelitian dibidang farmasi yang sangat aktif akhir-akhir ini. Obat-obatan yang menargetkan protein GPCR masuk dalam kategori kelompok obat 
terbesar yang disetujui oleh badan pangan dan obat di Amerika Serikat atau US-Food and Drug Administrasi (FDA) (Sriram \& Insel, 2018).

Tabel 5. Tren pemodelan homologi pada desain dan pengembangan obat dan agen antiviral HIV dan Zika (3 tahun terakhir)

\begin{tabular}{|c|c|c|c|c|c|}
\hline No & Protein & Ligan & Fungsi biologis & $\begin{array}{c}\text { Program } \\
\text { pemodelan } \\
\text { homologi } \\
\text { komparatif }\end{array}$ & Referensi \\
\hline 1 & $\begin{array}{l}\text { G Protein- } \\
\text { coupled } \\
\text { Estrogen } \\
\text { Receptor } 1 \\
\text { (GPER-1) }\end{array}$ & $\begin{array}{l}\text { Hormon estrogen, } \\
\text { peptide kecil, } \\
\text { molekul G1 }\end{array}$ & $\begin{array}{l}\text { Sinyal insulin, } \\
\text { regulasi tekanan } \\
\text { darah, sel } \\
\text { proliferasi }\end{array}$ & $\begin{array}{l}\text { MODELLER v } \\
\text { 9.15, SWISS- } \\
\text { MODEL }\end{array}$ & $\begin{array}{l}\text { (Bruno et al., } \\
\text { 2016) } \\
\text { (S. U. Khan et al., } \\
\text { 2019) }\end{array}$ \\
\hline 2 & $\begin{array}{l}\text { G Protein- } \\
\text { coupled } \\
\text { Receptor } 17 \\
\text { (GPR17) }\end{array}$ & $\begin{array}{l}\text { Nukleotida uracil, } \\
\text { leukotriena } \\
\text { sisteinil, } \\
\text { MDL29951 }\end{array}$ & $\begin{array}{l}\text { Sistem saraf } \\
\text { sentral }\end{array}$ & $\begin{array}{l}\text { MODELLER } \\
\text { versi 9.9, } \\
\text { BLAST, } \\
\text { PROCHECK, } \\
\text { ERRAT } \\
\end{array}$ & $\begin{array}{c}\text { (Saravanan et al., } \\
\text { 2018, p. 17) }\end{array}$ \\
\hline 3 & $\begin{array}{l}\text { Reseptor } \\
\text { polipeptida } \\
\text { pankreas } \\
\text { NPY4R }\end{array}$ & $\begin{array}{c}\text { Polipetida } \\
\text { pankreatik (PP) }\end{array}$ & $\begin{array}{c}\text { Regulasi sinyal } \\
\text { metabolisme lipid, } \\
\text { rasa } \\
\text { lapar/kenyang, } \\
\text { sekresi insulin }\end{array}$ & $\begin{array}{l}\text { MODELLER, } \\
\text { MolProbity }\end{array}$ & $\begin{array}{c}\text { (Shebanits et al., } \\
\text { 2019) }\end{array}$ \\
\hline 4 & $\begin{array}{c}\text { Enzim } \\
\text { polymerase } \\
\text { RNA virus Zika }\end{array}$ & $\begin{array}{l}\text { Asam } \\
\text { ribonukleosida } \\
\text { (RNA) }\end{array}$ & $\begin{array}{l}\text { Replikasi, siklus } \\
\text { hidup virus }\end{array}$ & $\begin{array}{c}\text { PHYRE2, } \\
\text { CLUSTAL } \\
\text { Omega, SAVES }\end{array}$ & (Elfiky, 2016) \\
\hline 5 & $\begin{array}{c}\text { Enzim protease } \\
\text { HIV }\end{array}$ & Polipeptida & $\begin{array}{l}\text { Pembentukan } \\
\text { protein virus }\end{array}$ & $\begin{array}{l}\text { SWISS MODEL, } \\
\text { PROCHECK }\end{array}$ & $\begin{array}{l}\text { (Zondagh et al., } \\
\text { 2018) }\end{array}$ \\
\hline
\end{tabular}

Bruno et al (2016) berhasil mengembangkan model homologi GPER-1 (G Proteincoupled Estrogen Receptor 1) menggunakan software MODELLER versi 9.11 yang digunakan dalam penyaringan virtual dan identifikasi senyawa-senyawa aktivator baru. GPER-1 merupakan protein reseptor transmembran yang terhubung dengan protein $\mathrm{G}$ dan salah satu anggota keluarga besar protein GPCR. GPER-1 berinteraksi dengan hormon estrogen yang mengaktifkan jalur persinyalan insulin, regulasi tekanan darah dan sel proliferasi. Bruno et al (2016) menggunakan protein cetakan CXCR4 (dengan asam amino yang mirip 50\%, asam amino yang sama 25\%) yang struktur kristalnya membentuk kompleks dengan molekul kecil IT1t dengan resolusi 2,5 Angstrom untuk menghasilkan model 3D GPER-1. Model ini digunakan untuk menghasilkan kompleks dengan molekul G1 yang merupakan molekul activator dari GPER-1. Simulasi dinamika molekuler selama $100 \mathrm{~ns}$ menunjukkan stabilitas yang tinggi dari kompleks G1/GPER-1 yang sangat 
berperan untuk mempelajari fungsi farmakologis dari molecule G1. Model yang dihasilkan berperan penting untuk menguraikan dasar struktural dan mekanisme yang mendasari kemampuan estrogen untuk mengikat GPER-1. Selain itu model GPER-1 yang dhasilkan dapat digunakan untuk melakukan penyaringan virtual terhadap modulator aktif yang lain yang berpotensi sebagai obat baru. Sementara itu Khan et al (2019) menggunakan model 3D GPER-1 yang dibangun dengan MODELLER dan SWISS MODEL berhasil mengidentifikasi sebanyak 100 senyawa aktif hasil dari virtual skrining terhadap 7 juta senyawa kimia di database yang memiliki aktivitas antiproliferatif yang tinggi dan berpotensi sebagai obat penyakit kanker.

Sarvanan et al (2018) telah berhasil melakukan pemodelan sruktur G Proteincoupled Receptor 17 (GPR17). GPR17 secara filogenetik berhubungan dengan reseptor purinergik yang merupakan target potensial untuk desain dan pengembangan obat-obatan penyakit seperti multiple sklerosis, Parkinson, Alzheimer dan kanker. Berdasarkan model GPR17 yang dibangun, dua senyawa aktivator baru yang selektif berhasil dideteksi yaitu AC1MLNKK dan T0510.3657 yang menunjukkan profil interaksi yang lebih baik daripada ligan yang dikenal sebelumnya yaitu MDL29951 menggunakan teknik docking dan dinamika molekuler. Validasi ex vivo dari interaksi ligan GPR17 memberikan bukti bahwa ligan T0510-3657 dan AC1MLNKK menghambat level cAMP di sel GPR17-HEK293T, dengan nilai pEC50 masing-masing 4,79 dan 4,64. Dengan penemuan ini dua senyawa AC1MLNKK dan T0510.3657 dapat dikembangkan lebih lanjut sebagai aktivator potensial GPR17 untuk tujuan terapi.

Shebanits et al (2019) juga telah memanfaatkan pemodelan homologi komparatif dengan menggunakan MODELLER dan validasi MolProbity dalam membangun beberapa model varian mutan dari protein reseptor neuronpeptida NPY4R. Hal ini dilakukan untuk mengetahui efek dari mutasi pada protein NPY4R terhadap interaksinya dengan ligan alamiahnya yaitu polipeptida pankreatik (PP). Efek mutasi pada NPY4R sebelumnya telah diketahui berkaitan erat dengan obesitas dan diabetes. Pada keadaan normal interaksi PP dengan NPYY4R akan menghambat sinyal biologis yang mengaktifkan perasaan lapar (satiety). Mutasi pada residu asam amino penyusun protein NPY4R akan mempengaruhi interaksi dengan PP di situs aktif yang kemudian akan meningkatkan rasa lapar dan konsumsi diet yang bisa mencetus obesitas. Penelitian oleh Shebanits et al (2019) ini menunjukkan bagaimana penerapan pemodelan homologi komparatif tidak hanya berguna dalam memahami interaksi antara reseptor NPY4R dan ligan PP tapi juga memberikan pengetahuan penting terhadap efek mutasi terhadap fungsi protein yang diharapkan akan sangat berguna di dalam pengembangan agen terapi sindrom metabolik di masa depan.

\section{Enzim polimerase RNA virus Zika.}

Kondisi kepala bayi yang kecil dari ukuran semestinya (mikrosefalus) baru-baru ini telah dilaporkan berkaitan dengan kondisi ibu yang terinfeksi virus Zika (Mlakar et al., 2016). Elfiky (2016) dalam studinya memanfaatkan program pemodelan homologi PHYRE2 dalam membangun model 3D enzim polymerase RNA yang berperan dalam proses replikasi dan pematangan virus Zika. Model yang dibangun ini kemudian digunakan untuk melakukan skrining secara virtual senyawa-senyawa kimia baru yang berinteraksi dan menghambat kerja enzim polymerase RNA sehingga menghambat pertumbuhan virus Zika. Hasil penelitian Elfiky (2016) mendapatkan dan merekomendasikan dua inhibitor nukleotida yaitu IDX-184 dan MK0608 yang dapat diujikan lebih lanjut sebagai agen antiviral terhadap infeksi Zika. 


\section{Enzim protease $\mathrm{HIV}$}

Enzim protease HIV adalah target obat antiretroviral yang penting karena peran utamanya dalam pematangan virus penyebab penyakit AIDS ini. Model komputasi telah berhasil digunakan untuk memahami dinamika varian-varian enzim protease HIV akibat mutasi. Zondagh et al (2018) menggunakan program SWISS MODEL untuk membangun model enzim protease HIV yang normal dan yang telah mengalami mutasi akibat perubahan asam amino Asparagin pada posisi 37 menjadi Treonin (N37T) pad virus HIV tipe C asal Afrika Selatan. Model ini kemudian divalidasi stereokimianya menggunakan program PROCHECK. Hasil penelitian menunjukkan bahwa model 3D enzim protease HIV yang telah mengalami mutasi N37T mengalami penurunan interaksi dengan obatobatan antiviral seperti lopinavir, atazanavir dan darunavir. Hal ini dikarenakan mutasi N37T merubah lansekap enzim protease HIV yang mengakibatkan berkurangnya kontak kimia dengan agen antiviral tersebut. Penelitian ini mampu menunjukkan peranan pemodelan homologi komparatif dalam menjelaskan efek mutasi yang menyebabkan resistansi virus HIV terhadap agen antiviral yang tersedia.

\section{PENUTUP}

Pemodelan homologi komparatif secara komputasional telah menjadi tren dan strategi baru yang digunakan dalam memprediksi struktur 3D protein ditengah masih sedikitnya protein penting lain yang berhasil dielusidasi melalui eksperimen biologi struktural. Hal ini disebabkan karena pemodelan homologi komparatif merupakan metode komputasional yang paling akurat dalam memprediksi struktur 3D protein target dengan berdasarkan sedikitnya 30\% kemiripan susunan asam amino dengan struktur protein cetakan. Pemodelan homologi komparatif juga mampu mengeksplorasi mekanisme interaksi antara protein target dan ligan dalam skala atomic; hal yang tidak bisa didapatkan melalui eksperimen. Dengan ini, jika diterapkan dengan bijak dan terus dikembangkan maka pemodelan homologi komparatif komputasional dapat mengakselerasi riset tentang desain dan pengembangan obat dalam mengatasi penyakit yang masih terus eksis di tengah masyarakat.

\section{DAFTAR PUSTAKA}

Berman, H. M., Westbrook, J., Feng, Z., Gilliland, G., Bhat, T. N., Weissig, H., Shindyalov, I. N., Bourne, P. E. (2000). The protein data bank. Nucleic Acids Research, 28(1), 235-242.

Bruno, A., Aiello, F., Costantino, G., \& Radi, M. (2016). Homology Modeling, Validation and Dynamics of the G Protein-coupled Estrogen Receptor 1 (GPER-1). Molecular Informatics, 35(8-9), 333-339.

Cavasotto, C. N., \& Phatak, S. S. (2009). Homology modeling in drug discovery: Current trends and applications. Drug Discovery Today, 14(13-14), 676-683.

Chen, V. B., Arendall, W. B., Headd, J. J., Keedy, D. A., Immormino, R. M., Kapral, G. J., Wang, X., Murray, L. W., Arendall III, W. B., Snoeyink, J., Richardson, D. C. (2010). MolProbity: All-atom structure validation for macromolecular crystallography. Acta Crystallographica Section D: Biological Crystallography, 66(1), 12-21. 
Colovos, C., \& Yeates, T. O. (1993). Verification of protein structures: Patterns of nonbonded atomic interactions. Protein Science, 2(9), 1511-1519.

Cothia, C., \& Lensk, A. M. (1986). The relation between the divergence of sequence and structure in proteins. $E M B O, 5(4), 823-826$.

Davis, A. M., Teague, S. J., \& Kleywegt, G. J. (2003). Application and limitations of Xray crystallographic data in structure-based ligand and drug design. Angewandte Chemie International Edition, 42(24), 2718-2736.

Eisenberg, D., Lüthy, R., \& Bowie, J. U. (1997). [20] VERIFY3D: Assessment of protein models with three-dimensional profiles. In Macromolecular Crystallography Part B: Vol. 277. Methods in Enzymology (pp. 396-404).

Elfiky, A. A. (2016). Zika viral polymerase inhibition using anti-HCV drugs both in market and under clinical trials. Journal of Medical Virology, 88(12), 2044-2051.

Eswar, N., Webb, B., Marti-Renom, M. A., Madhusudhan, M. S., Eramian, D., Shen, M., Pieper. U., Sali, A. (2006). Comparative Protein Structure Modeling Using Modeller. Current Protocols in Bioinformatics, 15(1), 5.6.1-5.6.30.

Fiser, A. (2017). Comparative protein structure modelling. In From Protein Structure to Function with Bioinformatics (pp. 91-134). Springer.

França, T. C. C. (2015). Homology modeling: An important tool for the drug discovery. Journal of Biomolecular Structure and Dynamics, 33(8), 1780-1793.

Ginalski, K. (2006). Comparative modeling for protein structure prediction. Current Opinion in Structural Biology, 16(2), 172-177.

Hauser, A. S., Attwood, M. M., Rask-Andersen, M., Schiöth, H. B., \& Gloriam, D. E. (2017). Trends in GPCR drug discovery: New agents, targets and indications. Nature Reviews Drug Discovery, 16(12), 829-842.

Hildebrand, A., Remmert, M., Biegert, A., \& Söding, J. (2009). Fast and accurate automatic structure prediction with HHpred. Proteins: Structure, Function, and Bioinformatics, 77(S9), 128-132.

Hillisch, A., \& Hilgenfeld, R. (2003). The role of protein 3D-structures in the drug discovery process. In Modern Methods of Drug Discovery (pp. 157-181). Springer.

Hooft, R. W. W. (1996). Errors in protein structures. Nature, 381(6580), 272.

Jones, D. T. (1999). Protein secondary structure prediction based on positionspecific scoring matrices. J Mol Biol, 292(2), 195-202.

Kalyaanamoorthy, S., \& Chen, Y.-P. P. (2011). Structure-based drug design to augment hit discovery. Drug Discovery Today, 16(17-18), 831-839.

Kelley, L. A. (2017). Fold recognition. In From Protein Structure to Function with Bioinformatics (pp. 59-90). Springer.

Al-Kimia |Volume 8 Nomor 12020100 
Kelley, L. A., Mezulis, S., Yates, C. M., Wass, M. N., \& Sternberg, M. J. E. (2015). The Phyre2 web portal for protein modeling, prediction and analysis. Nature Protocols, $10(6), 845-858$.

Khan, F. I., Wei, D.-Q., Gu, K.-R., Hassan, M. I., \& Tabrez, S. (2016). Current updates on computer aided protein modeling and designing. International Journal of Biological Macromolecules, 85, 48-62.

Khan, S. U., Ahemad, N., Chuah, L.-H., Naidu, R., \& Htar, T. T. (2019). Sequential ligandand structure-based virtual screening approach for the identification of potential $\mathrm{G}$ protein-coupled estrogen receptor-1 (GPER-1) modulators. RSC Advances, 9(5), $2525-2538$.

Kim, D. E., Chivian, D., \& Baker, D. (2004). Protein structure prediction and analysis using the Robetta server. Nucleic Acids Research, 32(suppl_2), W526-W531.

Laskowski, R. A., MacArthur, M. W., Moss, D. S., \& Thornton, J. M. (1993). PROCHECK: A program to check the stereochemical quality of protein structures. Journal of Applied Crystallography, 26(2), 283-291.

Lee, J., Freddolino, P. L., \& Zhang, Y. (2017). Ab initio protein structure prediction. In From Protein Structure to Function with Bioinformatics (pp. 3-35). Springer.

Lobley, A., Sadowski, M. I., \& Jones, D. T. (2009). pGenTHREADER and pDomTHREADER: New methods for improved protein fold recognition and superfamily discrimination. Bioinformatics, 25(14), 1761-1767.

Lounnas, V., Ritschel, T., Kelder, J., McGuire, R., Bywater, R. P., \& Foloppe, N. (2013). Current progress in structure-based rational drug design marks a new mindset in drug discovery. Computational and Structural Biotechnology Journal, 5(6), e201302011.

Lybrand, T. P. (1995). Ligand - protein docking and rational drug design. Current Opinion in Structural Biology, 5(2), 224-228.

Mandal, S., Moudgil, M., \& Mandal, S. K. (2009). Rational drug design. European Journal of Pharmacology, 625(1-3), 90-100.

McGinnis, S., \& Madden, T. L. (2004). BLAST: at the core of a powerful and diverse set of sequence analysis tools. Nucleic Acids Research, 32(2), W20-W25.

Mlakar, J., Korva, M., Tul, N., Popović, M., Poljšak-Prijatelj, M., Mraz, J., Kolenc, M., Rus, KR., Vipotnik, T. V., Vodusek, V. F., Vizjak, A., Pizem, J., Petrovec, M., Zupanc, T. A.. (2016). Zika virus associated with microcephaly. New England Journal of Medicine, 374(10), 951-958.

Moult, J., \& Melamud, E. (2000). From fold to function. Current Opinion in Structural Biology, 10(3), 384-389. 
Murata, K., \& Wolf, M. (2018). Cryo-electron microscopy for structural analysis of dynamic biological macromolecules. Biochimica et Biophysica Acta (BBA)-General Subjects, 1862(2), 324-334.

Nero, T. L., Parker, M. W., \& Morton, C. J. (2018). Protein structure and computational drug discovery. Biochemical Society Transactions, 46(5), 1367-1379.

Orengo, C. A., Todd, A. E., \& Thornton, J. M. (1999). From protein structure to function. Current Opinion in Structural Biology, 9(3), 374-382.

Pontius, J., Richelle, J., \& Wodak, S. J. (1996). Deviations from Standard Atomic Volumes as a Quality Measure for Protein Crystal Structures. Journal of Molecular Biology, 264(1), 121-136.

Remmert, M., Biegert, A., Hauser, A., \& Söding, J. (2012). HHblits: lightning-fast iterative protein sequence searching by HMM-HMM alignment. Nat. Methods, 9, 173-175.

Roy, A., Kucukural, A., \& Zhang, Y. (2010). I-TASSER: A unified platform for automated protein structure and function prediction. Nature Protocols, 5(4), 725.

Šali, A., \& Blundell, T. L. (1993). Comparative protein modelling by satisfaction of spatial restraints. Journal of Molecular Biology, 234(3), 779-815.

Saravanan, K. M., Palanivel, S., Yli-Harja, O., \& Kandhavelu, M. (2018). Identification of novel GPR17-agonists by structural bioinformatics and signaling activation. International Journal of Biological Macromolecules, 106, 901-907.

Saudale, F. Z. (2020). Pemodelan Molekuler: Prediksi dan Validasi Struktur 3D Protein in silico. Literasi Nusantara. Malang

Saudale, F. Z., Lerrick, R. I., Parikesit, A. A., \& Mariti, F. (2019). Chemistry Teachers' Awareness, Understanding, and Confidence toward Computational Tools for Molecular Visualization. Jurnal Pendidikan IPA Indonesia, 8(4), 436-446.

Saudale, F. Z., \& Suatu, I. R. S. (2020). Pemodelan Homologi Komparatif FABP Belalang Kembara (Locusta migratoria) dengan PHYRE2 dan Skrining Virtual Inhibitor Potensial. Indo. J. Chem. Res., 7(2), 127-140.

Schwede, T. (2013). Protein modeling: What happened to the "protein structure gap"? Structure, 21(9), 1531-1540.

Schwede, T., Kopp, J., Guex, N., \& Peitsch, M. C. (2003). SWISS-MODEL: An automated protein homology-modeling server. Nucleic Acids Research, 31(13), 3381-3385

Shebanits, K., Vasile, S., Xu, B., Gutiérrez-de-Terán, H., \& Larhammar, D. (2019). Functional characterization in vitro of twelve naturally occurring variants of the human pancreatic polypeptide receptor NPY4R. Neuropeptides.In Press

Shi, Y. (2014). A glimpse of structural biology through X-ray crystallography. Cell, 159(5), 995-1014. 
Sievers, F., Wilm, A., Dineen, D., Gibson, T. J., Karplus, K., Li, W., Lopez, R., McWilliam, H., Remmert, M., Soding, J., Thompson, J. D., Higgins, D. G. (2011). Fast, scalable generation of high-quality protein multiple sequence alignments using Clustal Omega. Molecular Systems Biology, 7, 539.

Sippl, M. (1993). Recognition of errors in three-dimensional structures of proteins. Proteins, 17(4), 355-362.

Skolnick, J., \& Fetrow, J. S. (2000). From genes to protein structure and function: Novel applications of computational approaches in the genomic era. Trends in Biotechnology, 18(1), 34-39.

Slabinski, L., Jaroszewski, L., Rodrigues, A. P., Rychlewski, L., Wilson, I. A., Lesley, S. A., \& Godzik, A. (2007). The challenge of protein structure determination-lessons from structural genomics. Protein Science, 16(11), 2472-2482.

Söding, J., Biegert, A., \& Lupas, A. N. (2005). The HHpred interactive server for protein homology detection and structure prediction. Nucleic Acids Research, 33(suppl_2), W244-W248.

Sriram, K., \& Insel, P. A. (2018). G protein-coupled receptors as targets for approved drugs: How many targets and how many drugs? Molecular Pharmacology, 93(4), 251-258.

Wang, T., Wu, M.-B., Zhang, R.-H., Chen, Z.-J., Hua, C., Lin, J.-P., \& Yang, L.-R. (2016). Advances in computational structure-based drug design and application in drug discovery. Current Topics in Medicinal Chemistry, 16(9), 901-916.

Webb, B., \& Sali, A. (2017). Protein structure modeling with MODELLER. In Functional Genomics (pp. 39-54). Springer.

Wiederstein, M., \& Sippl, M. J. (2007). ProSA-web: Interactive web service for the recognition of errors in three-dimensional structures of proteins. Nucleic Acids Research,35(suppl_2), W407-W410.

Xiang, Z. (2006). Advances in homology protein structure modeling. Current Protein and Peptide Science, 7(3), 217-227.

Zondagh, J., Balakrishnan, V., Achilonu, I., Dirr, H. W., \& Sayed, Y. (2018). Molecular dynamics and ligand docking of a hinge region variant of South African HIV-1 subtype C protease. Journal of Molecular Graphics and Modelling, 82, 1-11. 